\title{
RESPONSE OF RICE VARIETIES GROWN ON CALCAREOUS AND ACID MIXED SOILS AMENDED BY VERMICOMPOST UNDER VARIABLE CLIMATES
}

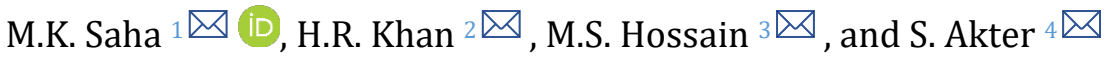 \\ 1,2,3,4 Department of Soil, Water and Environment, University of Dhaka, Dhaka-1000, Bangladesh.
}

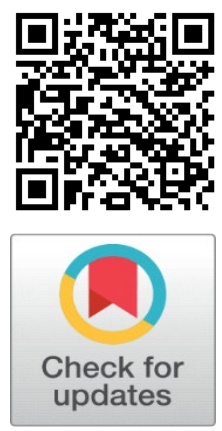

Received 5 August 2021

Accepted 21 August 2021

Published 30 September 2021

\section{CorrespondingAuthor \\ M.K. Saha, mithunsaha37@du.ac.bd. \\ DOI \\ 10.29121/granthaalayah.v9.i9.2021. 4183}

Funding: This research received no specific grant from any funding agency in the public, commercial, or not-for-profit sectors.

Copyright: (C) 2021 The Author(s). This is an open access article distributed under the terms of the Creative Commons Attribution License, which permits unrestricted use, distribution, and reproduction in any medium, provided the original author and source are credited.

\section{ABSTRACT}

A field experiment was conducted to explore how rice (BINA Dhan 11 and BRRI Dhan 34) responds in modified soil and climatic conditions. They were planted on artificially prepared soil beds by mixing calcareous and acid soils in $1: 1$ and 1:3 ratios. Soil temperature (St) was elevated up to $20 \mathrm{C}$ over the diurnal ones. Moisture (M) was maintained at $50 \%, 70 \%$, and saturated $(100 \%)$ soil conditions. Vermicompost (V) was applied at the rates of 0,10 , and 15 tha- 1 . The number of tillers and plant height were recorded at 25 days intervals. The maximum number of 26 and 27 tillers for BINA Dhan 11 and BRRI Dhan 34 were recorded. The longest plant height was observed with the T10 (V15M100) treatment. The treatment T3 (V15M100) resulted in maximum fresh weight of shoot and shoot dry matter production for both rice varieties in 1:3 mixed soil. Both varieties performed well in 1:3 mixed soils and elevated temperature conditions, as observed for normal soils. This evidence concluded that the improvement of calcareous and acid soils through their mixing is a successful approach and confirmed by the treatments' usual responses on different rice growth parameters under these mixed soils.

Keywords: Soil Mixing, Soil Moisture, Soil Temperature, Vermicompost, And Response of Rice

\section{INTRODUCTION}

Bangladesh, an agriculture-based country, has always been considered as one of the fertile lands that support almost all types of crops throughout the year. About $14.79 \%$ of our nation's GDP is attributed to the agricultural sector and about $45 \%$ of our active laborers are surviving in this sector MoF (2017). Rice, being the staple food for the people of Bangladesh, stands top in case of production among the food crops covering about $75 \%$ of agricultural lands used for crop production. At present, global food production and climate change are major concerns. Climate change is the change in weather patterns that extends for a large period and can be attributed primarily to human activities. Climate change will significantly affect agriculture by increasing water demand, limiting crop productivity, and reducing water availability in areas where crop production is dependent solely on irrigation. Temperature and moisture are two major interacting physical properties that have pronounced effects on plant growth Onwuka (2016). As of 2017, there had not been a month with average global surface temperatures below the twentieth-century norm since February 1985 Lieberman and Gordon (2018). Bangladesh is one of the most suffered countries of the woes brought upon by climate change. A change in seasonal pattern has already been experienced which is a matter of great worry for the 
farmers who rely on agriculture.

In Bangladesh, there is an alarming concern of soil acidity in the northwest, north-central and northeast regions that covers about $27 \%$ of lands cultivated by 3.5 million farmers Solaiman (2014). On the other hand, soils of Gange's alluvium and adjoining areas are experiencing calcareousness problems to a significant degree. Soil reaction mainly controls the availability of essential elements. The acidic soil possesses high concentrations of phytotoxic aluminum, iron, manganese, and deficiencies of essential plant nutrients such as calcium, magnesium, and molybdenum Brady and Weil (2017). On the contrary, calcareous soils are abundant in base-forming elements but lack iron, manganese, copper, zinc, boron, etc. In both conditions, normal plant growth is hampered and yield tends to decrease. Considering the above facts of these soils, it is hypothesized that the excess or deficient amounts of the elements of one soil may have remedial effects for another. Accordingly, mixing acid and calcareous soils may have a productive soil that may contain almost all essential macro and micro-elements that are problematic in their entity. Moreover, rice is a staple food, which response well with Vermicompost. Hence, the Vermicompost as an organic amendment also considered testing its potential in these manipulated soils. Vermicompost helps in preventing plant diseases Rao et al. (2000). Besides, it can amend degraded soil by providing nutrition, improving soil structure, and at the same time creating favorable conditions for the microbes Emmanuel et al. (2016), Sultana et al. (2015), Sikuku et al. (2010), one of the major components of soil fertility. Therefore, vermicompost can play a vital role in crop production and may provide fruitful results regarding the present attempt to ensure food security on a sustainable basis.

Furthermore, several studies have been done over the years to find out how organic manures alone or in combination can affect crop production under different climatic conditions. However, a field trial of rice growth on the mixture of calcareous and acid soils is scanty. Against the above background, the present study was conducted to find out how the combined action of heat stress and moisture levels affect rice growth on mixed calcareous and acid soils and the efficacy of vermicompost as an amendment for these soils.

\section{MATERIALS AND METHODS}

A field experiment was conducted during Aman season at the premises of the Department of Soil, Water and Environment, University of Dhaka, Dhaka-1000 to evaluate the combined effect of temperature, moisture, and vermicompost on the growth performances of rice grown on different mixing ratios of acid and calcareous soils. Acid soil was collected from Binnapara, a village of the Chehelgazi union of Dinajpur Sadar Upazilla in the Dinajpur district. And the calcareous soil was collected from West Gangabardi, a village of the Krishnanagar union of Faridpur Sadar Upazilla in the Faridpur district. Soils were collected from a medium highland agricultural field. The calcareous soils of West Gangabardi belong to the Sara series, whereas, the acid soil of Binnapara belongs to the Pirgacha series. The soils of the Sara series have the characteristics like Loamy texture, low water holding capacity, and partially flooded during monsoon. On the other hand, the Pirgacha series include soils with silt loam texture, seasonally flooded, moderately well-drained condition, and comparatively low soil reaction SRDI (2012). The collected calcareous and acid soils were dried, sieved $(2 \mathrm{~mm})$, and then incorporated these calcareous and acid soils into 1:1 and 1:3 ratios, respectively to prepare the mixed soils. After mixing these two opposite-natured soils, the resulting mixed soils might have changed properties. Accordingly, the selected physical, chemical, and 
physicochemical properties of the original and mixed soils were analyzed and are presented in Table 1 . Then the mixed soils were transferred to the fields to make artificial beds of $30 \times 30 \mathrm{~cm}$. The BINA Dhan 11 and BRRI Dhan 34 were collected by the courtesy of the BRRI and were planted as test crops. Experiments were conducted under field conditions maintaining soil moisture at 50\%, 75\% and saturated $(100 \%)$ soil conditions along with a temperature rise of $10 \mathrm{C}$ and $20 \mathrm{C}$ than those of the diurnal soil temperatures (26-280C). Three different doses $(0,10$, and $15 \mathrm{t}$ ha-1) of vermicompost collected from the local market were applied in the field plot as per experimental design. The selected composition of Vermicompost used is presented in Table 2. The treatment combinations of the experiment are presented in table 3. Hot water was poured into the metal pipes inserted below the ground to increase the soil temperature (Figure 1). The heating practices were continued for a set of 15 days starting from 25 days after transplantation (DAT) and 50 DAT, and the duration of temperature rise was around 6 hours a day. Four soil thermometers as replications were inserted into the ground of each subplot to examine and record the temperature rise (Figure 2). A number of tillers and plant heights were recorded at 25,50 , and 75 DAT. Then the plants were harvested at $1.0 \mathrm{~cm}$ above ground level and immediately fresh weight was taken with the help of a digital weight machine. Then they were oven-dried at 650C, and the dry weights were recorded through desiccation. Statistical analysis of the data was done using Microsoft Excel and Minitab 2019 software. As per contribution, the second author was the Project Director and Supervisor of the rest three authors. We were involved in the project as MS Thesis Students and conducted the experiments by sharing our technical knowledge regarding the improvement of soil health under variable climates. In the case of manuscript preparation, the first author made the initial draft. All authors went through and finally approved the manuscript.

\begin{tabular}{|c|c|c|c|c|}
\hline Properties & $\begin{array}{l}\text { Acid } \\
\text { soil }\end{array}$ & $\begin{array}{c}\text { Calcareous } \\
\text { soil }\end{array}$ & $\begin{array}{l}\text { Calcareous:Acid } \\
(1: 1) \text { mixed soil }\end{array}$ & $\begin{array}{l}\text { Calcareous:Acid } \\
(1: 3) \text { mixed soil }\end{array}$ \\
\hline Texture & $\begin{array}{l}\text { Silt } \\
\text { Loam }\end{array}$ & Loam & Silty Loam & Silty Loam \\
\hline Gravimetric Water Content (\%) & 2.94 & 1.79 & 2.87 & 1.88 \\
\hline Soil Reaction (pH) & 4.3 & 8.4 & 6.6 & 6.3 \\
\hline Electric Conductivity $(\mu \mathrm{S} / \mathrm{cm})$ & 397 & 2.11 & 143.4 & 121.4 \\
\hline Organic Carbon (\%) & 0.73 & 0.66 & 0.67 & 0.58 \\
\hline $\begin{array}{c}\text { Cation Exchange Capacity } \\
(\mathrm{cmol} / \mathrm{kg})\end{array}$ & 14.6 & 26.2 & 24.5 & 23.0 \\
\hline Total N (mg/kg) & 791 & 1003 & 959.6 & 601.1 \\
\hline Available $\mathrm{NH}_{4}+(\mathrm{mg} / \mathrm{kg})$ & 6.7 & 10.2 & 8.52 & 7.78 \\
\hline Available $\mathrm{NO}_{3}^{-}(\mathrm{mg} / \mathrm{kg})$ & 51.0 & 65 & 49 & 42.2 \\
\hline Available P (mg/kg) & 6.3 & 11.7 & 10.4 & 11.9 \\
\hline Available K (cmol/kg) & 0.21 & 0.46 & 0.30 & 0.42 \\
\hline Available S (mg/kg) & 32.1 & 17.1 & 22.3 & 26.0 \\
\hline Available Ca (cmol/kg) & 8.6 & 18.9 & 14.5 & 11.87 \\
\hline Available $\mathrm{Mg}(\mathrm{cmol} / \mathrm{kg})$ & 1.28 & 4.3 & 1.3 & 1.79 \\
\hline Available $\mathrm{Na}(\mathrm{cmol} / \mathrm{kg})$ & 0.22 & 0.5 & 0.2 & 0.32 \\
\hline Available Fe (mg/kg) & 121.2 & 13.1 & 63.7 & 48.6 \\
\hline Available Mn (mg/kg) & 43.5 & 9.6 & 29.3 & 19.8 \\
\hline Available Zn (mg/kg) & 2.1 & 1.48 & 1.99 & 2.1 \\
\hline Available $\mathrm{Cu}$ (mg/kg) & 0.89 & 1.21 & 0.95 & 1.2 \\
\hline
\end{tabular}




\begin{tabular}{|cccc|}
\hline \multicolumn{3}{|c|}{ Table 2 Selected composition of Vermicompost (Eisenia fetida) used } \\
\hline Content (\%) & No species & $\begin{array}{c}\text { Eudrilus } \\
\text { euginae }\end{array}$ & Eisenia fetida \\
\hline Organic C & 18.9 & 16.1 & 14.9 \\
\hline Total N & 1.23 & 1.14 & 1.11 \\
\hline C: N & 15.4 & 14.1 & 13.4 \\
\hline Total P & 0.63 & 0.64 & 0.66 \\
\hline Total K & 0.63 & 0.57 & 0.58 \\
\hline Total S & 0.33 & 0.28 & 0.29 \\
\hline Total Ca & 0.94 & 0.89 & 0.87 \\
\hline Total Mg & 0.81 & 0.76 & 0.82 \\
\hline
\end{tabular}

Table 3 Combinations of the treatments applied in the field experiment

\begin{tabular}{|c|c|c|}
\hline \multicolumn{3}{|c|}{ Treatment } \\
\hline Number & Denotation & Explanation \\
\hline $\mathrm{T}_{1}$ (control) & ${ }^{*} \mathrm{St}_{0}{ }^{\#} \mathrm{~V}_{0} \& \mathrm{M}_{50}$ & \multirow{5}{*}{$\begin{array}{l}{ }^{*} \mathrm{St}_{0} \text { is the normal soil temperature and } \mathrm{St}_{1}, \mathrm{St}_{2} \\
\text { indicates } 1^{\circ} \mathrm{C} \text { and } 2^{\circ} \mathrm{C} \text { rise in soil temperature } \\
\text { over the diurnal ones for a particular period. }\end{array}$} \\
\hline $\mathrm{T}_{2}$ & $\mathrm{St}_{1} \mathrm{~V}_{10} \mathrm{M}_{100}$ & \\
\hline $\mathrm{T}_{3}$ & $\mathrm{~V}_{15} \mathrm{M}_{70}$ & \\
\hline $\mathrm{T}_{4}$ & $\mathrm{~V}_{10} \mathrm{M}_{50}$ & \\
\hline $\mathrm{T}_{5}$ & $\mathrm{~V}_{15} \mathrm{M}_{50}$ & \\
\hline $\mathrm{T}_{6}$ & $\mathrm{~V}_{0} \mathrm{M}_{70}$ & \multirow{4}{*}{$\begin{array}{l}{ }^{\#} V_{0}, V_{10} \text {, and } V_{15} \text { are the rates of vermicompost of } \\
0,10 \text {, and } 15 \text { tha }^{-1} \text {, respectively. }\end{array}$} \\
\hline $\mathrm{T}_{7}$ & $\mathrm{~V}_{10} \mathrm{M}_{70}$ & \\
\hline $\mathrm{T}_{8}$ & $\mathrm{~V}_{0} \mathrm{M}_{100}$ & \\
\hline $\mathrm{T}_{9}$ & $\mathrm{~V}_{10} \mathrm{M}_{100}$ & \\
\hline $\mathrm{T}_{10}$ & $\mathrm{~V}_{15} \mathrm{M}_{100}$ & \multirow{9}{*}{$\begin{array}{l}\& \mathrm{M}_{50}, \mathrm{M}_{70} \text {, and } \mathrm{M}_{100} \text { indicate } 50 \%, 70 \% \text {, and } \\
\text { saturated soil moisture conditions, } \\
\text { respectively. }\end{array}$} \\
\hline $\mathrm{T}_{11}$ & $\mathrm{St}_{2} \mathrm{~V}_{10} \mathrm{M}_{70}$ & \\
\hline $\mathrm{T}_{12}$ & $\mathrm{St}_{1} \mathrm{~V}_{10} \mathrm{M}_{70}$ & \\
\hline $\mathrm{T}_{13}$ & $\mathrm{St}_{1} \mathrm{~V}_{15} \mathrm{M}_{70}$ & \\
\hline $\mathrm{T}_{14}$ & $\mathrm{St}_{2} \mathrm{~V}_{15} \mathrm{M}_{70}$ & \\
\hline $\mathrm{T}_{15}$ & $\mathrm{St}_{2} \mathrm{~V}_{15} \mathrm{M}_{100}$ & \\
\hline $\mathrm{T}_{16}$ & $\mathrm{St}_{2} \mathrm{~V}_{10} \mathrm{M}_{100}$ & \\
\hline $\mathrm{T}_{17}$ & $\mathrm{St}_{1} \mathrm{~V}_{0} \mathrm{M}_{70}$ & \\
\hline $\mathrm{T}_{18}$ & $\mathrm{St}_{1} \mathrm{~V}_{15} \mathrm{M}_{100}$ & \\
\hline
\end{tabular}




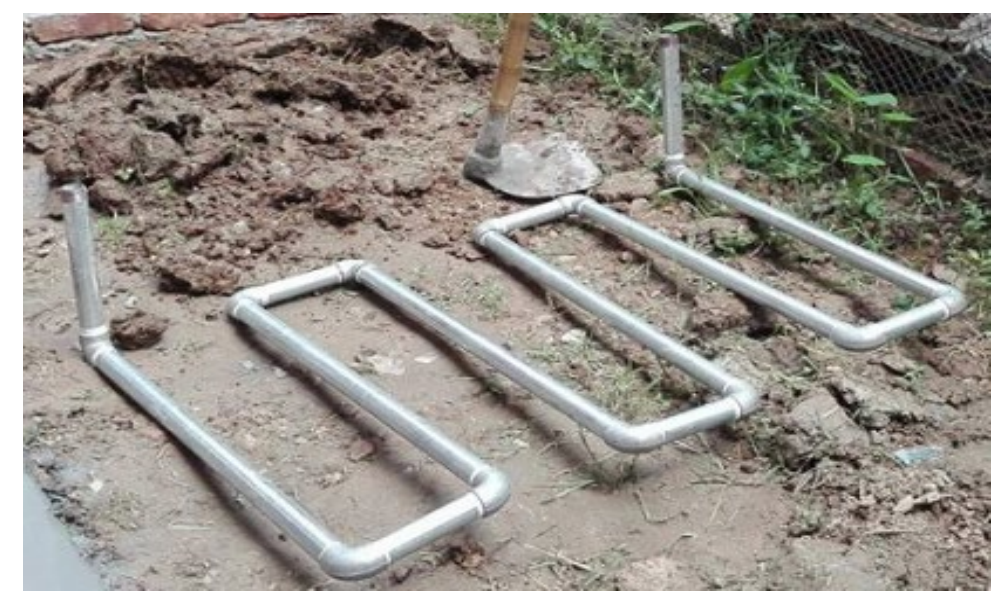

Figure 1 Instruments used for holding hot water

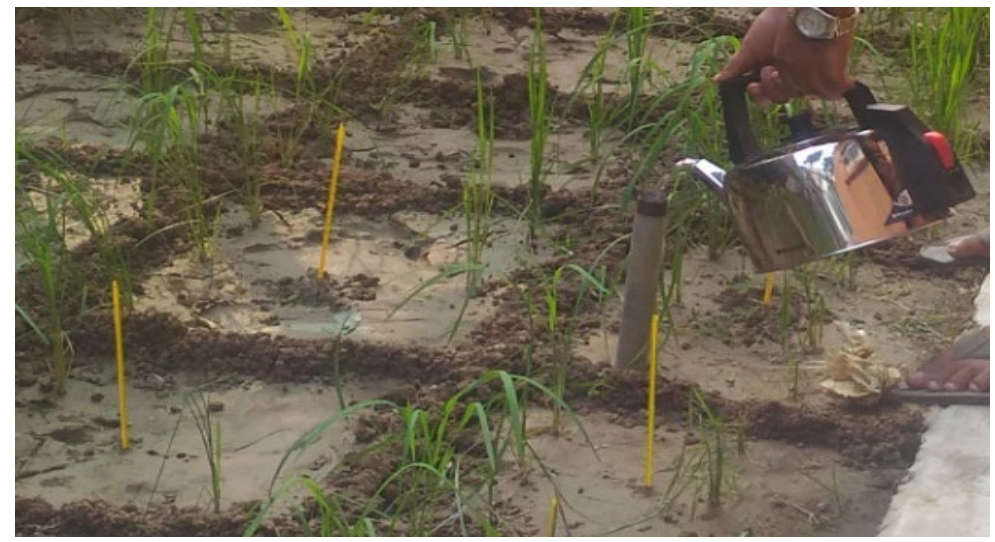

Figure 2 Approaches for rising and measurement of soil temperatures

\section{RESULTS AND DISCUSSION}

Significance of vegetative growth of crops: Vegetative growth of crops is represented by their height, tiller production, leaf area, stem, root, etc. organs. The amount of growth was quantitatively expressed as an increase in length of stem and root or other organs of plants, an increase in the area of leaves, and an increase in dry weight and fresh weight increment of the plant. The yield of crops may be considered in biological as well as agricultural terms. Biological yield has been as total production of plant material by a crop whereas economical yield or commercial yield takes into account only those plant organs for which particular crops are cultivated and harvested Holydays (1976). Moreover, plant height, tiller production, and fresh or dry weights of crops have special significance regarding planning and policymaking for land management and fodder production.

Production of Tillers: The production of total numbers of tillers varied with rice varieties, different ratios of mixed soils, and applied treatments. For BINA Dhan 11, the treatment T14 (St2V15M70) and T13 (St1V15M70) produced maximum productive tillers of 25 and 26 in the 1:1 and 1:3 mixed soils, respectively (Table 4). While the treatment T16 (St2V10M100) attained the maximum number of productive tillers of 26 and 27 by BRRI Dhan 34 grown in the same ratios of $1: 1$ and 1:3 mixed soils, respectively. The minimum number of productive tillers for BINA Dhan 11 were 5 and 6 in the control plot, whereas these numbers were 11 and 10 
for BRRI Dhan 34 grown in 1:1 and 1:3 mixed soils, respectively. Moreover, the total production of tillers by 18 treatments for BINA Dhan 11 and BRRI Dhan 34 were 311,330 , and 362,369 in 1:1 and 1:3 mixed soils, respectively (Table 4). The total tiller counts were found to be decreased in a few sub-plots at the harvesting stage of rice, which might be the usual natural phenomenon. The overall performances as observed by the treatments resembled that both the rice cultivars were better suited in 1:3 soils. Though, BRRI Dhan 34 was found comparatively better for tiller production than that of BINA Dhan 11. For both, the varieties of rice, elevated temperatures of soils played a significant $(\mathrm{p} \leq 0.05)$ positive role in the production of tillers regardless of soils and other treatments (Table 4). The increments of the number of tillers at increased levels of soil temperatures were might be due to more release of nutrients through higher microbial activities at high temperatures (29310C). The highest doses of vermicompost (V15) were found to have a positive significant $(\mathrm{p} \leq 0.05)$ influence on the tiller production for both BINA Dhan 11 and BRRI Dhan 34 varieties grown in 1:1 and 1:3 mixed soils (Table 4). Positive effects of vermicompost on tiller production of rice were reported by previous researchers Dekhane et al. (2014).

Table 4 Effects of different treatments on tiller production at chronological days after transplantation (DAT) of BINA Dhan 11 and BRRI Dhan 34 grown in 1:1 and 1:3, Calcareous-Acid mixed soils

\begin{tabular}{|c|c|c|c|c|c|c|c|c|c|c|c|c|c|}
\hline \multicolumn{14}{|c|}{ Number of tillers of rice plants per plot } \\
\hline \multicolumn{2}{|c|}{ Treatment } & \multicolumn{6}{|c|}{ BINA Dhan 11} & \multicolumn{6}{|c|}{ BRRI Dhan 34} \\
\hline & & \multicolumn{3}{|c|}{ 1:1 mixed soil } & \multicolumn{3}{|c|}{ 1:3 mixed soil } & \multicolumn{3}{|c|}{ 1:1 mixed soil } & \multicolumn{3}{|c|}{ 1:3 mixed soil } \\
\hline \multirow[t]{2}{*}{ No } & Denotation & 25 & 50 & 75 & 25 & 50 & 75 & 25 & 50 & 75 & 25 & 50 & 75 \\
\hline & & DAT & DAT & DAT & DAT & DAT & DAT & DAT & DAT & DAT & DAT & DAT & DAT \\
\hline $\mathrm{T}_{1}$ & $\mathrm{St}_{0} \mathrm{~V}_{0} \mathrm{M}_{50}$ & 5 & 9 & $8 \mathrm{~h}$ & 6 & 9 & $9 \mathrm{i}$ & 5 & 7 & $12 \mathrm{~g}$ & 4 & 9 & $10 \mathrm{f}$ \\
\hline $\mathrm{T}_{2}$ & $\mathrm{St}_{1} \mathrm{~V}_{10} \mathrm{M}_{100}$ & 9 & 15 & $\begin{array}{c}18 \\
\text { cdef }\end{array}$ & 11 & 16 & $\begin{array}{c}18 \\
\text { cdef }\end{array}$ & 10 & 27 & $25 \mathrm{ab}$ & 10 & 16 & $26 a$ \\
\hline $\mathrm{T}_{3}$ & $\mathrm{~V}_{15} \mathrm{M}_{70}$ & 12 & 19 & $\begin{array}{c}21 \\
\text { abcd }\end{array}$ & 10 & 18 & $\begin{array}{c}20 \\
\text { bcde }\end{array}$ & 11 & 15 & $\begin{array}{c}24 \\
\mathrm{abc}\end{array}$ & 11 & 18 & $\begin{array}{l}25 \\
a b\end{array}$ \\
\hline $\mathrm{T}_{4}$ & $\mathrm{~V}_{10} \mathrm{M}_{50}$ & 6 & 10 & $9 \mathrm{gh}$ & 8 & 10 & $\begin{array}{c}12 \\
\text { ghi }\end{array}$ & 8 & 14 & $\begin{array}{l}16 \\
\text { efg }\end{array}$ & 8 & 10 & $\begin{array}{l}17 \\
\text { de }\end{array}$ \\
\hline $\mathrm{T}_{5}$ & $\mathrm{~V}_{15} \mathrm{M}_{50}$ & 8 & 11 & $\begin{array}{c}13 \\
\text { fgh }\end{array}$ & 9 & 12 & $\begin{array}{c}13 \\
\text { fghi }\end{array}$ & 9 & 16 & $\begin{array}{c}19 \\
\text { cdef }\end{array}$ & 10 & 12 & $\begin{array}{c}20 \\
\text { bcd }\end{array}$ \\
\hline $\mathrm{T}_{6}$ & $\mathrm{~V}_{0} \mathrm{M}_{70}$ & 7 & 10 & $\begin{array}{c}14 \\
\text { efg }\end{array}$ & 7 & 9 & $\begin{array}{c}15 \\
\text { efgh }\end{array}$ & 7 & 19 & $\begin{array}{c}19 \\
\text { cdef }\end{array}$ & 8 & 9 & $\begin{array}{c}20 \\
\text { bcd }\end{array}$ \\
\hline $\mathrm{T}_{7}$ & $\mathrm{~V}_{10} \mathrm{M}_{70}$ & 10 & 15 & $\begin{array}{c}19 \\
\text { bcde }\end{array}$ & 11 & 16 & $\begin{array}{c}21 \\
\text { abcd }\end{array}$ & 9 & 17 & $\begin{array}{c}20 \\
\text { bcde }\end{array}$ & 9 & 16 & $\begin{array}{c}20 \\
\text { bcd }\end{array}$ \\
\hline $\mathrm{T}_{8}$ & $\mathrm{~V}_{0} \mathrm{M}_{100}$ & 8 & 11 & $\begin{array}{l}15 \\
\text { ef }\end{array}$ & 8 & 10 & $\begin{array}{c}16 \\
\operatorname{defg}\end{array}$ & 8 & 15 & $\begin{array}{l}16 \\
\text { efg }\end{array}$ & 9 & 10 & $\begin{array}{c}18 \\
\text { cde }\end{array}$ \\
\hline $\mathrm{T}_{9}$ & $\mathrm{~V}_{10} \mathrm{M}_{100}$ & 10 & 17 & $\begin{array}{c}16 \\
\text { def }\end{array}$ & 11 & 16 & $\begin{array}{c}20 \\
\text { bcde }\end{array}$ & 9 & 15 & $\begin{array}{c}18 \\
\text { def }\end{array}$ & 12 & 16 & $\begin{array}{l}19 \\
\mathrm{~cd}\end{array}$ \\
\hline $\mathrm{T}_{10}$ & $\mathrm{~V}_{15} \mathrm{M}_{100}$ & 11 & 14 & $\begin{array}{c}17 \\
\text { cdef }\end{array}$ & 12 & 16 & $\begin{array}{c}19 \\
\text { cde }\end{array}$ & 11 & 16 & $\begin{array}{c}22 \\
\text { abcd }\end{array}$ & 11 & 16 & $\begin{array}{c}20 \\
\text { bcd }\end{array}$ \\
\hline $\mathrm{T}_{11}$ & $\mathrm{St}_{2} \mathrm{~V}_{10} \mathrm{M}_{70}$ & 11 & 13 & $\begin{array}{c}19 \\
\text { bcde }\end{array}$ & 10 & 15 & $\begin{array}{c}19 \\
\text { cde }\end{array}$ & 10 & 19 & $\begin{array}{c}21 \\
\text { abcde }\end{array}$ & 11 & 15 & $\begin{array}{c}22 \\
a b c\end{array}$ \\
\hline $\mathrm{T}_{12}$ & $\mathrm{St}_{1} \mathrm{~V}_{10} \mathrm{M}_{70}$ & 10 & 17 & $\begin{array}{l}24 \\
a b\end{array}$ & 11 & 19 & $\begin{array}{l}25 \\
a b\end{array}$ & 10 & 20 & $\begin{array}{c}24 \\
a b c\end{array}$ & 12 & 19 & $\begin{array}{c}23 \\
a b c\end{array}$ \\
\hline
\end{tabular}


Response of Rice Varieties Grown on Calcareous and Acid Mixed Soils Amended by Vermicompost Under Variable Climates

\begin{tabular}{|c|c|c|c|c|c|c|c|c|c|c|c|c|c|}
\hline $\mathrm{T}_{13}$ & $\mathrm{St}_{1} \mathrm{~V}_{15} \mathrm{M}_{70}$ & 8 & 19 & $\begin{array}{c}21 \\
\text { abcd }\end{array}$ & 9 & 20 & $26 \mathrm{a}$ & 8 & 14 & $\begin{array}{c}19 \\
\text { cdef }\end{array}$ & 8 & 20 & $\begin{array}{l}19 \\
\mathrm{~cd}\end{array}$ \\
\hline $\mathrm{T}_{14}$ & $\mathrm{St}_{2} \mathrm{~V}_{15} \mathrm{M}_{70}$ & 11 & 26 & $25 \mathrm{a}$ & 11 & 21 & $\begin{array}{c}23 \\
a b c\end{array}$ & 11 & 22 & $25 a b$ & 10 & 21 & $\begin{array}{l}25 \\
a b\end{array}$ \\
\hline $\mathrm{T}_{15}$ & $\mathrm{St}_{2} \mathrm{~V}_{15} \mathrm{M}_{100}$ & 10 & 13 & $\begin{array}{c}22 \\
\mathrm{abc}\end{array}$ & 12 & 14 & $\begin{array}{c}21 \\
\text { abcd }\end{array}$ & 9 & 17 & $\begin{array}{c}22 \\
\text { abcd }\end{array}$ & 11 & 14 & $\begin{array}{c}23 \\
a b c\end{array}$ \\
\hline $\mathrm{T}_{16}$ & $\mathrm{St}_{2} \mathrm{~V}_{10} \mathrm{M}_{100}$ & 8 & 11 & $\begin{array}{c}17 \\
\text { cdef }\end{array}$ & 10 & 13 & $\begin{array}{c}18 \\
\text { cdef }\end{array}$ & 10 & 25 & $26 \mathrm{a}$ & 12 & 13 & $27 \mathrm{a}$ \\
\hline $\mathrm{T}_{17}$ & $\mathrm{St}_{1} \mathrm{~V}_{0} \mathrm{M}_{70}$ & 6 & 10 & 9 gh & 6 & 10 & $\begin{array}{l}10 \\
\text { hi }\end{array}$ & 7 & 9 & $14 \mathrm{fg}$ & 8 & 10 & $\begin{array}{l}13 \\
\text { ef }\end{array}$ \\
\hline $\mathrm{T}_{18}$ & $\mathrm{St}_{1} \mathrm{~V}_{15} \mathrm{M}_{100}$ & 10 & 22 & $\begin{array}{l}24 \\
a b\end{array}$ & 11 & 20 & $\begin{array}{l}25 \\
a b\end{array}$ & 10 & 22 & $\begin{array}{c}20 \\
\text { bcde }\end{array}$ & 11 & 20 & $\begin{array}{c}22 \\
\text { abcd }\end{array}$ \\
\hline
\end{tabular}

In a column, values followed by a common letter are not significantly different but values with different letters vary significantly at $5 \%$ level by Tukey's Range Test

Height of Rice Plants: The average height of rice plants measured in 3 growth stages of rice revealed that with the advent of time, the height of the plants increased with increased levels of moisture, temperature, and vermicompost treatments. These effects were more pronounced in 1:3 mixed soils (Table 5). The results demonstrated that average heights of BINA Dhan 11 and BRRI Dhan 34 were 78.9, 78.4 , and $86.4,87.1 \mathrm{~cm}$ in $1: 1$ and $1: 3$ mixed soils, respectively, which claimed that BRRI Dhan 34 exerted overall 8-9 cm tallest height than that of BINA Dhan 11 grown in 1:3 mixed soil. The height of rice varieties was found to have a positive relationship with the soil temperature rising to 20C. Treatment T10 (V15M100) had the highest positive impact on the height of both rice varieties and the lowest mean value of height was obtained by the control plot with treatment T1 (St0V0M50) in both soils. The longest height for BINA Dhan 11 was $94 \mathrm{~cm}$ and $97 \mathrm{~cm}$ in 1:1 and 1:3 mixed soils, respectively. Whereas, for BRRI Dhan 34, the respective longest plant heights were $98 \mathrm{~cm}$ and $103 \mathrm{~cm}$. Though, the treatment T16 (St2V10M100) also had a similar contribution in resulting in the longest plant height $(98 \mathrm{~cm})$ for BRRI Dhan 34 in 1:1 mixed soil. The effects of the treatment T14 (St2V15M70) on this parameter of both varieties were quite notable (Table 5). This might be due to the fact that vermicompost releases a portion of nutrients readily and the rest amounts gradually later on; which supports the nutrition of the plant throughout its life cycle. Another prior experiment was affirmed that the height of the rice plant increases significantly with vermicompost Pramanik (2007). The effects of different moisture levels in the different ratios of mixed soils did not show any definite trends of effects but played a positive role on the growth performances regardless of rice varieties and other treatments.

Table 5 Effects of different treatments on plant height $(\mathrm{cm})$ at chronological days after transplantation (DAT) of BINA Dhan 11 and BRRI Dhan 34 grown in 1:1 and 1:3, Calcareous-Acid mixed soils

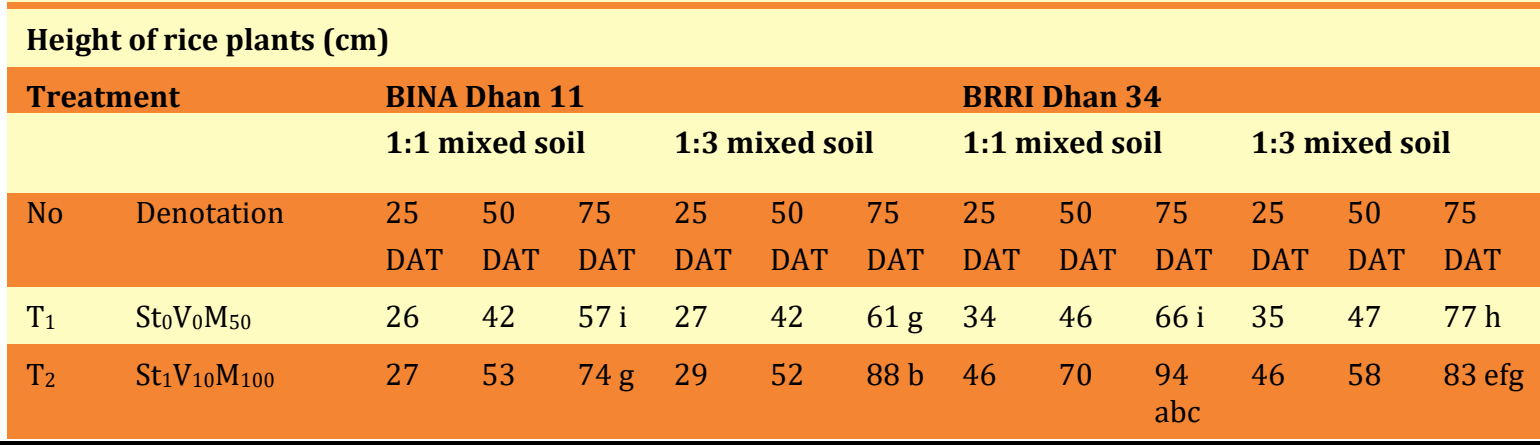


M.K. Saha, H.R. Khan, M.S. Hossain, and S. Akter

\begin{tabular}{|c|c|c|c|c|c|c|c|c|c|c|c|c|c|}
\hline $\mathrm{T}_{3}$ & $\mathrm{~V}_{15} \mathrm{M}_{70}$ & 33 & 63 & $\begin{array}{l}91 \\
\mathrm{abc}\end{array}$ & 37 & 66 & $87 \mathrm{~b}$ & 45 & 62 & $\begin{array}{l}83 \\
\text { ef }\end{array}$ & 50 & 71 & $90 \mathrm{~cd}$ \\
\hline $\mathrm{T}_{4}$ & $\mathrm{~V}_{10} \mathrm{M}_{50}$ & 27 & 40 & $61 \mathrm{i}$ & 34 & 50 & $\begin{array}{l}68 \\
\text { ef }\end{array}$ & 42 & 55 & $\begin{array}{l}74 \\
\text { gh }\end{array}$ & 44 & 55 & $\begin{array}{l}81 \\
\text { fgh }\end{array}$ \\
\hline $\mathrm{T}_{5}$ & $\mathrm{~V}_{15} \mathrm{M}_{50}$ & 37 & 60 & $\begin{array}{l}78 \\
\text { fg }\end{array}$ & 38 & 62 & $\begin{array}{l}77 \\
\mathrm{~cd}\end{array}$ & 46 & 50 & $\begin{array}{l}75 \\
\text { gh }\end{array}$ & 47 & 60 & 83 efg \\
\hline $\mathrm{T}_{6}$ & $\mathrm{~V}_{0} \mathrm{M}_{70}$ & 29 & 42 & $62 \mathrm{i}$ & 28 & 44 & $62 \mathrm{~g}$ & 40 & 60 & $\begin{array}{l}71 \\
\text { hi }\end{array}$ & 38 & 57 & 83 efg \\
\hline $\mathrm{T}_{7}$ & $\mathrm{~V}_{10} \mathrm{M}_{70}$ & 30 & 60 & $\begin{array}{l}86 \\
\mathrm{~cd}\end{array}$ & 31 & 60 & $89 \mathrm{~b}$ & 43 & 68 & $\begin{array}{l}90 \\
\mathrm{~cd}\end{array}$ & 42 & 70 & 92 bc \\
\hline $\mathrm{T}_{8}$ & $\mathrm{~V}_{0} \mathrm{M}_{100}$ & 40 & 50 & $\begin{array}{l}86 \\
\mathrm{~cd}\end{array}$ & 28 & 68 & $88 \mathrm{~b}$ & 45 & 68 & $\begin{array}{l}81 \\
\text { ef }\end{array}$ & 38 & 70 & $80 \mathrm{gh}$ \\
\hline $\mathrm{T}_{9}$ & $\mathrm{~V}_{10} \mathrm{M}_{100}$ & 35 & 57 & $\begin{array}{l}88 \\
\text { bcd }\end{array}$ & 33 & 48 & $78 \mathrm{c}$ & 49 & 70 & $97 \mathrm{a}$ & 42 & 66 & $93 \mathrm{bc}$ \\
\hline $\mathrm{T}_{10}$ & $\mathrm{~V}_{15} \mathrm{M}_{100}$ & 38 & 65 & $94 \mathrm{a}$ & 34 & 63 & $97 \mathrm{a}$ & 50 & 70 & $98 \mathrm{a}$ & 51 & 70 & $103 a$ \\
\hline $\mathrm{T}_{11}$ & $\mathrm{St}_{2} \mathrm{~V}_{10} \mathrm{M}_{70}$ & 33 & 54 & $\begin{array}{l}83 \\
\text { def }\end{array}$ & 40 & 60 & $85 \mathrm{~b}$ & 45 & 62 & $\begin{array}{l}85 \\
\text { de }\end{array}$ & 52 & 69 & $93 \mathrm{bc}$ \\
\hline $\mathrm{T}_{12}$ & $\mathrm{St}_{1} \mathrm{~V}_{10} \mathrm{M}_{70}$ & 32 & 60 & $76 \mathrm{~g}$ & 33 & 65 & $89 \mathrm{~b}$ & 42 & 70 & $\begin{array}{l}89 \\
\mathrm{~cd}\end{array}$ & 50 & 65 & $88 \mathrm{cde}$ \\
\hline $\mathrm{T}_{13}$ & $\mathrm{St}_{1} \mathrm{~V}_{15} \mathrm{M}_{70}$ & 30 & 68 & $\begin{array}{l}84 \\
\text { de }\end{array}$ & 34 & 56 & $87 \mathrm{~b}$ & 45 & 70 & $\begin{array}{l}91 \\
b c\end{array}$ & 56 & 68 & $89 \mathrm{~cd}$ \\
\hline $\mathrm{T}_{14}$ & $\mathrm{St}_{2} \mathrm{~V}_{15} \mathrm{M}_{70}$ & 33 & 65 & $\begin{array}{l}92 \\
a b\end{array}$ & 37 & 45 & $\begin{array}{l}69 \\
\text { ef }\end{array}$ & 46 & 70 & $\begin{array}{l}96 \\
a b\end{array}$ & 40 & 55 & $96 \mathrm{~b}$ \\
\hline $\mathrm{T}_{15}$ & $\mathrm{St}_{2} \mathrm{~V}_{15} \mathrm{M}_{100}$ & 37 & 50 & $85 \mathrm{~d}$ & 45 & 40 & $\begin{array}{l}66 \\
\mathrm{fg}\end{array}$ & 41 & 67 & $\begin{array}{l}96 \\
a b\end{array}$ & 47 & 60 & $\begin{array}{l}88 \\
\text { cde }\end{array}$ \\
\hline $\mathrm{T}_{16}$ & $\mathrm{St}_{2} \mathrm{~V}_{10} \mathrm{M}_{100}$ & 36 & 52 & $\begin{array}{l}79 \\
\text { efg }\end{array}$ & 38 & 55 & $\begin{array}{l}73 \\
\text { cde }\end{array}$ & 41 & 70 & $98 \mathrm{a}$ & 40 & 65 & $\begin{array}{l}86 \\
\text { def }\end{array}$ \\
\hline $\mathrm{T}_{17}$ & $\mathrm{St}_{1} \mathrm{~V}_{0} \mathrm{M}_{70}$ & 29 & 49 & $68 \mathrm{~h}$ & 30 & 47 & $\begin{array}{l}72 \\
\text { de }\end{array}$ & 37 & 56 & $\begin{array}{l}78 \\
\text { fg }\end{array}$ & 38 & 50 & $79 \mathrm{gh}$ \\
\hline $\mathrm{T}_{18}$ & $\mathrm{St}_{1} \mathrm{~V}_{15} \mathrm{M}_{100}$ & 33 & 60 & $76 \mathrm{~g}$ & 30 & 48 & $\begin{array}{l}75 \\
\mathrm{~cd}\end{array}$ & 43 & 68 & $\begin{array}{l}93 \\
a b c\end{array}$ & 53 & 55 & $83 \mathrm{efg}$ \\
\hline
\end{tabular}

In a column, values followed by a common letter are not significantly different but values with different letters vary significantly at 5\% level by Tukey's Range Test

In a column, values followed by a common letter are not significantly different but values with different letters vary significantly at $5 \%$ level by Tukey's Range Test

Fresh Weight of Rice Shoots: The ANOVA and Tukey's range test showed that the fresh weight of rice plants significantly $(p \leq 0.05)$ increased with the increased rates of vermicompost, moisture, and temperature; and these effects were more pronounced in the ratio of 1:3 mixed soil (Table 6). The treatment T3 (V15M70) contributed the highest average fresh weight of rice shoot $(7.25$ and $6.99 \mathrm{~g} / \mathrm{plant}$ for BINA Dhan 11; 6.50 and 7.72 for BRRI Dhan 34 in $1: 1$ and 1:3 mixed soils, respectively) over control T1 (St0V0M50) which endorsed the lowest fresh weight (Table 6). The combination of vermicompost of $15 \mathrm{t}$ ha-1, the soil moisture level of $60 \%$, and a temperature rise of $10 \mathrm{C}$ over the normal soil temperature i.e., the treatment T13 produced the second-highest fresh weight for both varieties. This might be because vermicompost improves soil structure and thus water holding capacity of soil which can be attributed to improved water uptake by rice plants Tejada et al. (2009). Vermicompost has a positive effect on vegetative growth, 
stimulating shoot and root development which might be attributed to further increase in fresh weight Edwards et al. (2004).

\begin{tabular}{|c|c|c|c|c|c|}
\hline $\begin{array}{l}\text { Table } \\
\text { of BII }\end{array}$ & $\begin{array}{l}\text { ffects of diffe } \\
\text { han } 11 \text { and I }\end{array}$ & $\begin{array}{l}\text { treatments on } \\
\text { Dhan } 34 \text { grow }\end{array}$ & $\begin{array}{l}\text { esh weight }(\mathrm{g} / \mathrm{p} \\
\text { in } 1: 1 \text { and } 1: 3, \mathrm{C}\end{array}$ & $\begin{array}{l}\text { nt) at harvestin } \\
\text { careous-Acid m }\end{array}$ & $\begin{array}{l}\text { stage ( } 75 \text { DAT) } \\
\text { xed soils }\end{array}$ \\
\hline & eatment & & esh weight of ri & plants (g/plan & \\
\hline & & BINA I & Ian 11 & BRRI D & an 34 \\
\hline No & Denotation & 1:1 mixed soil & 1:3 mixed soil & 1:1 mixed soil & 1:3 mixed soil \\
\hline $\mathrm{T}_{1}$ & $\mathrm{St}_{0} \mathrm{~V}_{0} \mathrm{M}_{50}$ & $2.60 \mathrm{p}$ & 2.740 & 2.880 & $2.74 \mathrm{n}$ \\
\hline $\mathrm{T}_{2}$ & $\mathrm{St}_{1} \mathrm{~V}_{10} \mathrm{M}_{100}$ & $5.60 \mathrm{f}$ & $5.79 \mathrm{f}$ & $5.77 \mathrm{f}$ & $5.97 \mathrm{e}$ \\
\hline $\mathrm{T}_{3}$ & $\mathrm{~V}_{15} \mathrm{M}_{70}$ & $7.25 \mathrm{a}$ & $6.99 \mathrm{a}$ & $6.50 \mathrm{a}$ & $7.72 \mathrm{a}$ \\
\hline $\mathrm{T}_{4}$ & $\mathrm{~V}_{10} \mathrm{M}_{50}$ & $2.94 \mathrm{o}$ & $3.38 \mathrm{~m}$ & $2.99 \mathrm{n}$ & $3.50 \mathrm{k}$ \\
\hline $\mathrm{T}_{5}$ & $\mathrm{~V}_{15} \mathrm{M}_{50}$ & 4.171 & $4.98 \mathrm{j}$ & $4.23 \mathrm{k}$ & $4.49 \mathrm{j}$ \\
\hline $\mathrm{T}_{6}$ & $\mathrm{~V}_{0} \mathrm{M}_{70}$ & $3.86 \mathrm{~m}$ & 4.011 & 3.931 & $3.40 \mathrm{l}$ \\
\hline $\mathrm{T}_{7}$ & $\mathrm{~V}_{10} \mathrm{M}_{70}$ & $5.75 \mathrm{de}$ & $6.55 \mathrm{~b}$ & $5.77 \mathrm{f}$ & $6.06 \mathrm{~d}$ \\
\hline $\mathrm{T}_{8}$ & $\mathrm{~V}_{0} \mathrm{M}_{100}$ & $4.67 \mathrm{i}$ & $5.11 \mathrm{i}$ & $4.73 \mathrm{i}$ & $5.10 \mathrm{~g}$ \\
\hline $\mathrm{T}_{9}$ & $\mathrm{~V}_{10} \mathrm{M}_{100}$ & $5.31 \mathrm{~g}$ & $5.55 \mathrm{~h}$ & $5.25 \mathrm{~g}$ & $5.37 \mathrm{f}$ \\
\hline $\mathrm{T}_{10}$ & $\mathrm{~V}_{15} \mathrm{M}_{100}$ & $5.79 \mathrm{de}$ & $6.12 \mathrm{~d}$ & $5.93 \mathrm{~d}$ & $6.25 \mathrm{~b}$ \\
\hline $\mathrm{T}_{11}$ & $\mathrm{St}_{2} \mathrm{~V}_{10} \mathrm{M}_{70}$ & $5.80 \mathrm{~d}$ & $5.79 \mathrm{f}$ & $5.83 \mathrm{e}$ & $6.15 c$ \\
\hline $\mathrm{T}_{12}$ & $\mathrm{St}_{1} \mathrm{~V}_{10} \mathrm{M}_{70}$ & $5.94 \mathrm{c}$ & $6.45 \mathrm{c}$ & $6.02 \mathrm{c}$ & $6.27 \mathrm{~b}$ \\
\hline $\mathrm{T}_{13}$ & $\mathrm{St}_{1} \mathrm{~V}_{15} \mathrm{M}_{70}$ & $6.44 \mathrm{~b}$ & $6.55 b$ & $6.42 \mathrm{~b}$ & $6.28 \mathrm{~b}$ \\
\hline $\mathrm{T}_{14}$ & $\mathrm{St}_{2} \mathrm{~V}_{15} \mathrm{M}_{70}$ & $5.74 \mathrm{e}$ & $6.02 \mathrm{e}$ & $5.73 \mathrm{f}$ & $6.10 \mathrm{~cd}$ \\
\hline $\mathrm{T}_{15}$ & $\mathrm{St}_{2} \mathrm{~V}_{15} \mathrm{M}_{100}$ & $4.26 \mathrm{k}$ & $4.60 \mathrm{k}$ & $4.75 \mathrm{i}$ & $5.00 \mathrm{~h}$ \\
\hline $\mathrm{T}_{16}$ & $\mathrm{St}_{2} \mathrm{~V}_{10} \mathrm{M}_{100}$ & $4.58 \mathrm{j}$ & $5.73 \mathrm{~g}$ & $4.67 j$ & $4.74 \mathrm{i}$ \\
\hline $\mathrm{T}_{17}$ & $\mathrm{St}_{1} \mathrm{~V}_{0} \mathrm{M}_{70}$ & $3.06 n$ & $3.31 \mathrm{n}$ & $3.11 \mathrm{~m}$ & $3.20 \mathrm{~m}$ \\
\hline $\mathrm{T}_{18}$ & $\mathrm{St}_{1} \mathrm{~V}_{15} \mathrm{M}_{100}$ & $4.76 \mathrm{~h}$ & $4.96 \mathrm{j}$ & $4.96 \mathrm{~h}$ & $5.07 \mathrm{~g}$ \\
\hline
\end{tabular}

In a column, values followed by a common letter are not significantly different but values with different letters vary significantly at $5 \%$ level by Tukey's Range Test

Dry Weight of Rice Shoots: Average dry matter weight of rice shoot was found to be positively significant $(\mathrm{p} \leq 0.05)$ with the individual application of increased rates of vermicompost, while the combination of three treatments and their increased doses were more pronounced than those of their individual applications. The highest dry matter weight was recorded for the treatment T3 (V15M70) for BINA Dhan 11 in both the ratios of soils (2.01 and $3.28 \mathrm{~g} /$ plant, respectively), but for BRRI Dhan 34 only in 1:1 mixed soil ( $2.20 \mathrm{~g} / \mathrm{plant:}$ Table 7$)$. The treatment T12 (St1V10M70) contributed the highest dry weight ( $2.70 \mathrm{~g} / \mathrm{plant})$ for BRRI Dhan 34 in 1:3 mixed soils. For both the cases, the lowest dry weight was gained from control T1 $(0.66,0.71,0.89$, and $0.94 \mathrm{~g} /$ plant for BINA Dhan 11 and BRRI Dhan 34 in 1:1 and $1: 3$ mixed soils).

Table 7 Effects of different treatments on dry weight (g/plant) at harvesting stage (75 DAT) of BINA Dhan 11 and BRRI Dhan 34 in 1:1 and 1:3, Calcareous-Acid mixed soils

\section{Treatment}

Dry weight of rice plants (g/ plant)

\section{BINA Dhan 11}

1:1 mixed soil

1:3 mixed soil

BRRI Dhan 34 


\begin{tabular}{cccccc}
$\mathrm{T}_{1}$ & $\mathrm{St}_{0} \mathrm{~V}_{0} \mathrm{M}_{50}$ & $0.66 \mathrm{k}$ & $0.71 \mathrm{j}$ & $0.89 \mathrm{~m}$ & $0.94 \mathrm{~m}$ \\
$\mathrm{~T}_{2}$ & $\mathrm{St}_{1} \mathrm{~V}_{10} \mathrm{M}_{100}$ & $1.64 \mathrm{~d}$ & $1.80 \mathrm{~d}$ & $1.90 \mathrm{ef}$ & $1.99 \mathrm{e}$ \\
$\mathrm{T}_{3}$ & $\mathrm{~V}_{15} \mathrm{M}_{70}$ & $2.01 \mathrm{a}$ & $3.28 \mathrm{a}$ & $2.20 \mathrm{a}$ & $2.62 \mathrm{~b}$ \\
\hline $\mathrm{T}_{4}$ & $\mathrm{~V}_{10} \mathrm{M}_{50}$ & $0.93 \mathrm{j}$ & $1.15 \mathrm{~h}$ & $1.01 \mathrm{l}$ & $1.26 \mathrm{k}$ \\
$\mathrm{T}_{5}$ & $\mathrm{~V}_{15} \mathrm{M}_{50}$ & $1.06 \mathrm{i}$ & $1.57 \mathrm{f}$ & $1.41 \mathrm{i}$ & $1.53 \mathrm{i}$ \\
$\mathrm{T}_{6}$ & $\mathrm{~V}_{0} \mathrm{M}_{70}$ & $1.20 \mathrm{~h}$ & $1.09 \mathrm{i}$ & $1.33 \mathrm{j}$ & $1.40 \mathrm{j}$ \\
$\mathrm{T}_{7}$ & $\mathrm{~V}_{10} \mathrm{M}_{70}$ & $1.64 \mathrm{~d}$ & $1.99 \mathrm{~b}$ & $1.90 \mathrm{ef}$ & $2.00 \mathrm{e}$ \\
$\mathrm{T}_{8}$ & $\mathrm{~V}_{00} \mathrm{M}_{100}$ & $1.37 \mathrm{~g}$ & $1.48 \mathrm{~g}$ & $1.59 \mathrm{gh}$ & $1.70 \mathrm{~g}$ \\
$\mathrm{~T}_{9}$ & $\mathrm{~V}_{10} \mathrm{M}_{100}$ & $1.57 \mathrm{e}$ & $1.72 \mathrm{e}$ & $1.85 \mathrm{f}$ & $1.77 \mathrm{f}$ \\
$\mathrm{T}_{10}$ & $\mathrm{~V}_{15} \mathrm{M}_{100}$ & $1.60 \mathrm{de}$ & $1.93 \mathrm{c}$ & $1.98 \mathrm{~cd}$ & $2.06 \mathrm{~d}$ \\
$\mathrm{~T}_{11}$ & $\mathrm{St}_{2} \mathrm{~V}_{10} \mathrm{M}_{70}$ & $1.64 \mathrm{~d}$ & $1.77 \mathrm{de}$ & $1.94 \mathrm{de}$ & $2.20 \mathrm{c}$ \\
$\mathrm{T}_{12}$ & $\mathrm{St}_{1} \mathrm{~V}_{10} \mathrm{M}_{70}$ & $1.73 \mathrm{c}$ & $1.93 \mathrm{c}$ & $2.00 \mathrm{c}$ & $2.70 \mathrm{a}$ \\
\hline $\mathrm{T}_{13}$ & $\mathrm{St}_{1} \mathrm{~V}_{15} \mathrm{M}_{70}$ & $1.87 \mathrm{~b}$ & $1.96 \mathrm{bc}$ & $2.10 \mathrm{~b}$ & $2.16 \mathrm{c}$ \\
\hline $\mathrm{T}_{14}$ & $\mathrm{St}_{2} \mathrm{~V}_{15} \mathrm{M}_{70}$ & $1.61 \mathrm{de}$ & $1.91 \mathrm{c}$ & $1.91 \mathrm{e}$ & $2.00 \mathrm{e}$ \\
\hline $\mathrm{T}_{15}$ & $\mathrm{St}_{2} \mathrm{~V}_{15} \mathrm{M}_{100}$ & $1.20 \mathrm{~h}$ & $1.80 \mathrm{~d}$ & $1.61 \mathrm{gh}$ & $1.70 \mathrm{~g}$ \\
\hline $\mathrm{T}_{16}$ & $\mathrm{St}_{2} \mathrm{~V}_{10} \mathrm{M}_{100}$ & $1.40 \mathrm{~g}$ & $1.78 \mathrm{~d}$ & $1.57 \mathrm{~h}$ & $1.61 \mathrm{~h}$ \\
\hline $\mathrm{T}_{17}$ & $\mathrm{St}_{1} \mathrm{~V}_{0} \mathrm{M}_{70}$ & $0.95 \mathrm{j}$ & $1.07 \mathrm{i}$ & $1.11 \mathrm{k}$ & $1.02 \mathrm{l}$ \\
\hline $\mathrm{T}_{18}$ & $\mathrm{St}_{1} \mathrm{~V}_{15} \mathrm{M}_{100}$ & $1.48 \mathrm{f}$ & $1.57 \mathrm{f}$ & $1.64 \mathrm{~g}$ & $1.71 \mathrm{~g}$ \\
\hline
\end{tabular}

In a column, values followed by a common letter are not significantly different but values with different letters vary significantly at $5 \%$ level by Tukey's Range Test

The average dry weight of rice shoot of all the treatments was found to have $1.42,1.69$, and 1.66, $1.79 \mathrm{~g} /$ plant for BINA Dhan 11 and BRRI Dhan 34 grown in 1:1 and 1:3 mixed soils, respectively (Table 7). Further investigation made it vivid that the average dry weights were higher in temperature-treated plots. The mean value of dry weight in temperature-modified plots for BINA Dhan 11 were 1.48 and 1.72 $\mathrm{g} /$ plant. In the case of BRRI Dhan 34, these were 1.73 and $1.88 \mathrm{~g} / \mathrm{plant}$. The increased dry matter production at elevated soil temperatures were might be due to the quick release of plant nutrients through higher microbial activities at high temperatures (29-310C). It is known that the microbial activities were maximum at about $370 \mathrm{C}$ temperature. Moreover, rice growth was reported to the maximum at a soil temperature of 22-310C Baker and Allen (1993). In the case of scented rice, the application of vermicompost at a rate of 5 tha- 1 caused a significant increase in plant height, the number of tillers, and dry matter accumulation over no use of vermicompost Murali and Setty (2000).

\section{Correlation and regression analysis}

An attempt was made to determine whether there are relationships between the number of tillers and plant heights of the same variety at different DAT in both 1:1 and 1:3 mixed soils. The number of tillers and heights of BINA Dhan 11 and BRRI Dhan 34 showed a significant positive correlation in 1:1 mixed soil at different DAT, but in the case of 1:3 soils, a significant correlation was obtained only for the 25 DAT (Table 8). A significant positive relationship was attained between the tillers count and plant heights of BINA Dhan 11 at 5\%, 0.01\%, and 0.1\% level of probability for the particular 25, 50, and 75 DAT, where the corresponding R2 values are 0.2243 , $0.5676,0.4273$, respectively (Table 8 and Figure $3 a$ ). The same rice variety showed a non-significant correlation at 50 and 75 DAT in 1:3 mixed soils (Table 8 and Figure 3c). Almost similar types of relationships were detected in the case of BRRI Dhan 
34 , where, the correlation coefficient was significant at $0.01 \%, 0.1 \%$, and again $0.01 \%$ level at the consecutive DAT in 1:1 mixed soil (Table 8 and Figure $3 \mathrm{~d}$ ). Again, their regression analysis gives R2 values which explain $51.43 \%, 39.30 \%$, and 49.14 $\%$ data (Table 8 and Figure $3 \mathrm{~b}$ ). The present analyses revealed that numbers of tillers and the growth of the plants increased simultaneously for both rice varieties in 1:1 mixed soil but in the case of 1:3 mixed soils their relationships were positive but non-significant demonstrating that plant height and production of the tiller are not always have strong synergistic effects regarding growth and development of rice.

Table 8 Pearson correlation between the number of tillers and plant height of rice at 25, 50, and 75 DAT irrespective of types and amounts of treatments

\begin{tabular}{|c|c|c|c|c|}
\hline \multirow{2}{*}{$\begin{array}{c}\text { Days After Transplantation } \\
\text { (DAT) }\end{array}$} & \multicolumn{2}{|c|}{ BINA Dhan } & \multicolumn{2}{|c|}{ BRRI Dhan } \\
\hline & $\begin{array}{l}\text { 1:1 mixed } \\
\text { soil }\end{array}$ & $\begin{array}{l}\text { 1:3 mixed } \\
\text { soil }\end{array}$ & $\begin{array}{l}\text { 1:1 mixed } \\
\text { soil }\end{array}$ & $\begin{array}{l}\text { 1:3 mixed } \\
\text { soil }\end{array}$ \\
\hline 25 & $0.4736^{*}$ & $0.5022 *$ & $0.7172^{* * *}$ & $0.4706^{*}$ \\
\hline 50 & $0.7534^{* * *}$ & $0.1938 \mathrm{NS}$ & $0.6269^{* *}$ & $0.3583 \mathrm{NS}$ \\
\hline 75 & $0.6537^{* *}$ & $0.4526 \mathrm{NS}$ & $0.7010^{* * *}$ & $0.4419 \mathrm{NS}$ \\
\hline
\end{tabular}

$*, * *, * * *$ indicate the coefficient correlation (r) is significant at $5 \%, 1 \%, 0.1 \%$ level, respectively. NS means ( $\mathrm{r}$ ) is not significant at $5 \%$ level of probability
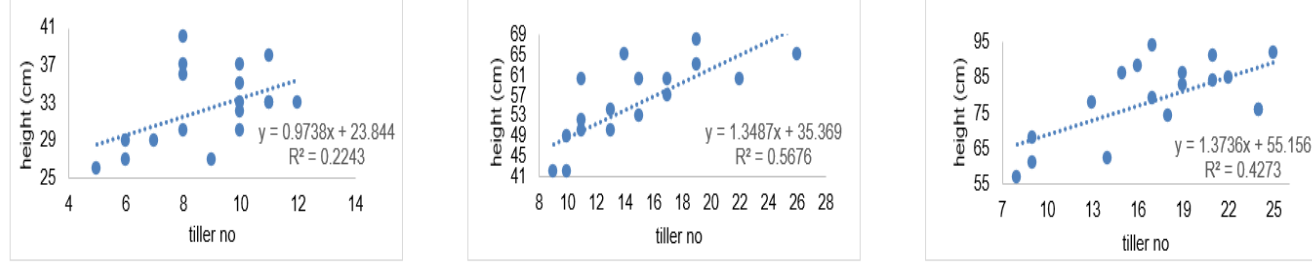

Figure 3a Regression line between the height and tiller count of BINA Dhan 11 in 1:1 soil at 25, 50, and 75 DAT of rice (left to right)
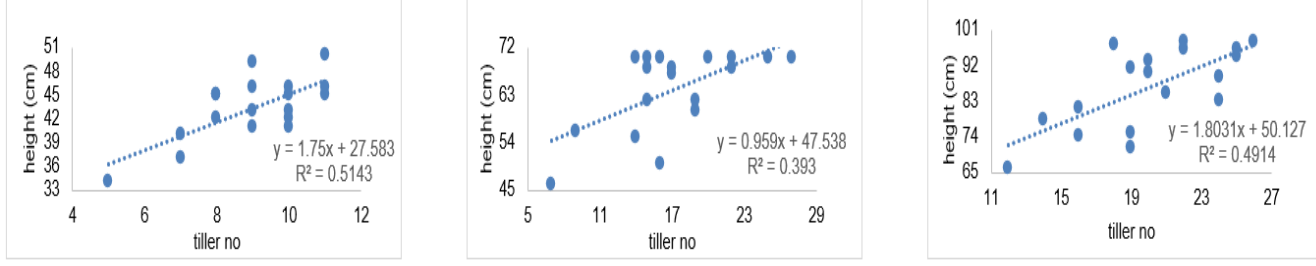

Figure 3b Regression line between the height and tiller count of BRRI Dhan 34 in 1:1 soil at 25, 50, and 75 DAT of rice (left to right)
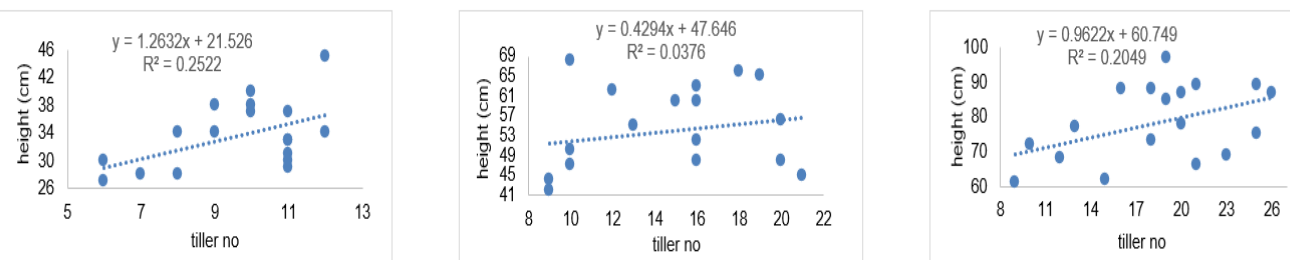

Figure 3c Regression line between the height and tiller count of BINA Dhan 11 in 1:3 soils at 25, 50, and 75 DAT of rice (left to right) 

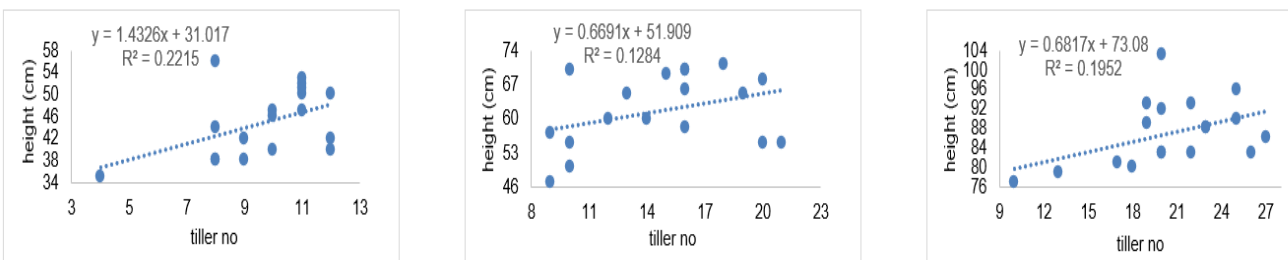

Figure 3d Regression line between the height and tiller count of BRRI Dhan 34 in 1:3 soils at 25, 50, and 75 DAT of rice (left to right)

\section{CONCLUSION}

Acidic and alkaline soils are not suitable for all types of crop production. The current study disclosed that rice could also be cultured profitably on the mixture of marginal calcareous and acid soils. The amalgamation of these soils in several ratios as per their ion concentrations in excess or deficient amounts was found to be effective for nutrient management in both the acid and calcareous soils. Between the rice varieties used, BRRI Dhan 34 performed well regardless of treatments. Increased soil temperature of $20 \mathrm{C}$ than that of the daily usual soil temperature was found to have immediate positive impacts on the growth of rice varieties. Vermicompost emerged as an efficient amendment in the modified soil conditions and in plant productions, which resembled that the approaches of soil mixing are successful techniques. However, further study is recommended to explore the longterm effects of these soil mixing techniques under variable soil-plant conditions.

\section{ACKNOWLEDGMENTS}

The study was carried out by the financial support of about 86,000 US \$ under a project of the Climate Change Trust Fund (CCTF) entitled 'Assessment of Impacts of Climate Change on Soil Health and Food Security, and Adaptation of Climatesmart Agriculture in Most Adversely Affected Areas of Bangladesh' funded by the Ministry of Environment, Forest and Climate Change (MoEFCC) (2017-18, DU 410), Government of the Peoples' Republic of Bangladesh. We are also grateful to the Ministry of Science and Technology for providing an NST (national science and technology) fellowship for the first author.

\section{REFERENCES}

Baker JT and Allen Jr LH (1993). Effects of carbon-di-oxide and temperature on rice: a summary of five growing seasons. J Agric Met, 48:575-582. Retrieved from https://doi.org/10.2480/agrmet.48.575

Brady NC and Weil RR (2017). The nature and properties of soils. Pearson Press, New Jersey.

Dekhane SS, Patel DJ, Jadhav PB, Kireeti A, Patil NB, Harad NB and Jadhav KP (2014). Effect of Organic and Inorganic Fertilizer on Growth and Yield of Paddy CV GR 11. Int J of Inf Res and Rev, 1(2):26-28.

Edwards CA, Domínguez J and Arancon NQ (2004). The influence of vermicomposts on plant growth and pest incidence. In: Shakir SH, Mikhail WZA (eds), Soil Zoolog for Sustainable Development in the 21st century, Cairo, pp 397-420. Retrieved from

http://jdguez.webs.uvigo.es/wp- 
content/uploads/2011/10/The-influence-of-vermicompost-on-plantgrowth-and-pest-incidence.pdf

Emmanuel P, Sylvester K and Lamo J (2016). Effect of Soil Moisture Stress Duration on the Growth Characteristics and Yield of Rice Cultivars. J of Agric and Env Sci, 5(2):66-76. Retrieved from http://hdl.handle.net/123456789/143

Holydays R (1976). The efficiency of solar energy conversion by the whole crop. In: Duckham AN, Jones JGW and Roberts EH (eds) Food production and consumption, North Holland Publishing Company, Amsterdam, pp 127-146. Retrieved from https://agris.fao.org/agrissearch/search.do?recordID=US201302967696

Lieberman B and Gordon E (2018). Climate change in human history. Bloomsbury, New York.

MoF (2017). Bangladesh Economic Review. Dissertation, Ministry of Finance, Government of the People's Republic of Bangladesh.

Murali MK and Setty RA (2000). Effect of levels of NPK, vermicompost and growth regulator (triacontanol) on growth and yield of scented rice. Mysore J of Agric Sci, 34(4):335-339. Retrieved from https://www.cabdirect.org/cabdirect/abstract/20033110988

Onwuka, BM (2016). Effects of soil temperature on Some Soil properties and plant growth. J of Agric Sci, 6(3):89-93. Retrieved from https://d1wqtxts1xzle7.cloudfront.net/56134964/Onwuka2-with-coverpage-v2.pdf?Expires=1631965783\&Signature=bW2HuGVBSNa2ZbQ2veOEmV63g2fwAbRLmS8FSDC6D-

ZRV8DimdZiAp7jXmJXs1C98bDPquNULIKUtkqIG2X lcKxn4I31SjG2br1t DOBL0X4VP497rzpZuM0MS9hL9H4CGZ6 AxSO8RvBp58pSCdZMZvgdYQ 01lIe6TvjQaLwMFfqg3pXo qDkyVstcjIXviwiSDAayYkBDjzPZlimOlVLENjm olGUXsHiktI9jLFkkrn1mzXB2piOQe3F Qks5HFb7-

p53t35jz0IJgTZugbCT10Njcwr8YBqpXwDYuT8CsURZNu0gvPzEOvBnD8 100CghcBV8Gw8ZV4hjqW2A_\&Key-Pair-Id=APKAJLOHF5GGSLRBV4ZA

Pramanik P (2007). Chemical and biochemical aspects of vermicomposts with reference to transplanted rice. PhD. dissertation, Visva Bharati University, Shantiniketan.

Rao KR, Rao PA and Rao KT (2000). Influence of organic manure and fertilizers on the incidence of groundnut leaf miner. Dev Ann of Plant Protection Sci, 9(1):12-15.

SRDI (Soil Resources Development Institute) (2012). Thana Nirdeshika reports of different districts of Bangladesh. Dissertation, Ministry of Agriculture, Bangladesh.

Sikuku PA, Netondo GW, Musyimi DM and Onyango JC (2010). Effects of water deficit on days to maturity and yield of three Nerica rainfed rice variety. ARPN J of Agric and Bio Sci, 5(3):1-3. Retrieved from https://repository.maseno.ac.ke/handle/123456789/2560

Solaiman ASM (2014). Land Degradation in Bangladesh: A Challenge to Face Food Security. Dissertation, Dept. of Agroforestry and Environment, Bangabandhu Sheikh Mujibur Rahman Agricultural University, Gazipur, Bangladesh.

Sultana MS, Rahman MH, Rahman MS, Sultana S and Paul AK (2015). Effect of integrated use of vermicompost, pressmud and urea on the nutrient content of grain and straw of rice (Hybrid Dhan Hira 2). Int J of Sci and Res Publ, 5(11):765-770. Retrieved from 
http://citeseerx.ist.psu.edu/viewdoc/download?doi=10.1.1.736.2766\&rep $=$ rep $1 \&$ type $=$ pdf\#page $=774$

Tejada M, Lomke J and Neesam K (2009). Effects of a vermicompost composted with beet vinasse on soil properties, soil losses and soil restoration. CATENA, 77(3):238-247.

Retrieved

from https://doi.org/10.1016/j.catena.2009.01.004 